Cooper, H., Vane, C.H., Evers, S., Aplin, P., Girkin, N., Sjogersten, S. 2019. From peat swamp forest to oil palm plantations: the stability of tropical peatland carbon. Geoderma 342, 109-117 https://doi.org/10.1016/j.geoderma.2019.02.021

\title{
From peat swamp forest to oil palm plantations: the stability of tropical peatland
}

\section{carbon}

Hannah Cooper ${ }^{1,2}$, Christopher H. Vane ${ }^{3}$, Stephanie Evers ${ }^{24}$, Paul Aplin ${ }^{5}$, Nicholas Girkin ${ }^{1}$, Sofie Sjogersten ${ }^{1 *}$

1

2

3

4

5

6

7

8

9

10

11

12

13

14

15

16

17

18

19

20

21

22

23

24

25

26

27

28

${ }^{1}$ School of Biosciences, University of Nottingham, UK

${ }^{2}$ School of Environmental and Geographical Sciences, University of Nottingham Malaysia Campus,

Malaysia

${ }^{3}$ British Geological Survey, Environmental Science Centre, Keyworth, UK

${ }^{4}$ School of Natural Sciences and Psychology, Liverpool John Moores University, UK

${ }^{5}$ Department of Geography, Edge Hill University, Ormskirk, UK

Correspondence and requests for materials should be addressed to sofie.sjogersten@nottingham.ac.uk

(1)

(1)

19

(1)


Cooper, H., Vane, C.H., Evers, S., Aplin, P., Girkin, N., Sjogersten, S. 2019. From peat swamp forest to oil palm plantations: the stability of tropical peatland carbon. Geoderma 342, 109-117 https://doi.org/10.1016/j.geoderma.2019.02.021

\section{Abstract}

Accurate inventory of tropical peatland carbon dynamics is important to (a) determine the size of the active carbon pool; (b) estimate the scale of transfers of peat-derived greenhouse gases to the atmosphere resulting from land use change; and (c) support carbon emissions reduction policies. To date, information on the quality of tropical peatland organic matter and its sensitivity to increases in global temperatures is limited, particularly in the context of land conversion. The aim of this work is therefore to determine peat quality and the temperature response of potential greenhouse gas (GHG) emissions under flooded conditions from tropical peatland sites reflecting the process of conversion from forest to oil palm plantation. Overall, surface peat carbon was more labile than deeper peats, with the largest labile pool at forest sites. In the later stages of land conversion, the relative abundance of recalcitrant organic material increased. Potential GHG fluxes were greatest in surface peats and declined as labile carbon was depleted following land conversion. Higher temperatures resulted in higher potential GHG emissions at all sites but the magnitude of the temperature response depended on organic matter lability. For $\mathrm{CO}_{2}$ fluxes, the temperature response was most pronounced at forest sites reflecting the greater peat lability at these sites. In contrast, higher temperatures resulted in increased $\mathrm{CH}_{4}$ emissions both at forest and converted sites. This suggests that increasing temperatures in response to climate warming may drive higher $\mathrm{CH}_{4}$ emissions from sites dominated by degraded organic matter. Collectively, this study demonstrates that the enhanced decomposition and reduced litter input rates, is reflected in reduced potential $\mathrm{CO}_{2}$ emissions but that higher temperature resulting from climate warming may maintain high GHG emissions at plantation sites. 
Cooper, H., Vane, C.H., Evers, S., Aplin, P., Girkin, N., Sjogersten, S. 2019. From peat swamp forest to oil palm plantations: the stability of tropical peatland carbon. Geoderma 342, 109-117 https://doi.org/10.1016/j.geoderma.2019.02.021 
Cooper, H., Vane, C.H., Evers, S., Aplin, P., Girkin, N., Sjogersten, S. 2019. From peat swamp forest to oil palm plantations: the stability of tropical peatland carbon. Geoderma 342, 109-117 https://doi.org/10.1016/j.geoderma.2019.02.021

\section{Introduction}

Palm oil is one of the most widely used agricultural products in the world, with demand projected to increase in the future (Corley, 2009; Koh and Wilcove, 2008; Vijay et al., 2016). Globally, the total land area of mature oil palm plantations increased from 3.5 Mha in 1975 to 18.7 Mha in 2014, and a large proportion of this increase occurred in Malaysia (rising from 0.4 Mha to 4.7 Mha) (FAOSTAT, 2014). An estimate by Koh and Wilcove (2008) indicated that of all oil palm expansion between 1990 and 2005 in Malaysia, at least 50\% has come at the expense of natural rainforest, of which the natural vegetation is predominantly peat swamp forest (PSF) (Davies et al., 2010). The most recent estimates indicate that 1.8 Mha of PSF were converted to oil palm plantation between 2007 and 2015, corresponding to a yearly average deforestation rate of $4.1 \%$ in Southeast Asia (Miettinen et al., 2016).

PSFs play an essential role in the global carbon cycle and are significant carbon sinks and stores, containing an estimated $15-19 \%$ of the global peat carbon stock (610 Gt C) (Dargie et al., 2017; Page, S.E., et al., 2011). The peats are formed in tropical humid zones where watersaturated soil inhibits shoot and root decomposition resulting in organic matter content of $65 \%$ or more (Comeau et al., 2013). Peats located in Southeast Asia often contain more than 90\% organic matter (Davies et al., 2010). However, PSFs are highly sensitive to disturbance by drainage or deforestation for conversion to oil palm plantations (Evers et al., 2017), and following conversion carbon accumulated over centuries or millennia is rapidly released to the atmosphere contributing to climate warming (Davies et al., 2010; Couwenberg et al., 2010; Hooijer et al., 2013; Moore et al., 2018).

It is well known that land use and land use change directly affects the exchange of greenhouse gases between terrestrial ecosystems and the atmosphere (IPCC, 2000). Within tropical 
Cooper, H., Vane, C.H., Evers, S., Aplin, P., Girkin, N., Sjogersten, S. 2019. From peat swamp forest to oil palm plantations: the stability of tropical peatland carbon. Geoderma 342, 109-117 https://doi.org/10.1016/j.geoderma.2019.02.021

peatlands, water-table height is a key regulator of litter decomposition, with water-logged, anoxic conditions driving formation of methane $\left(\mathrm{CH}_{4}\right)$ and aerobic environments driving the release of $\mathrm{CO}_{2}$ (Jauhiainen et al., 2005 and 2016; Couwenberg et al., 2010; Hoyos-Santillan et al., 2016). The high net primary production of the PSF itself is also important for maintaining high carbon accumulation rates (Sjogersten et al., 2014), as it provides inputs of root exudates, decaying roots, wood and leaf material into the peatland system (Hoyos-Santillan et al., 2015, Girkin et al., 2018), which is frequently halted through land conversion and deforestation, with direct implications for carbon storage and organic matter composition.

Since 1990, oil palm plantations have been linked to $2.5 \mathrm{Gt}$ C losses in carbon stock in tropical peatlands (Miettinen et al., 2017). There is, however, a lack of data regarding how rapidly carbon is lost to the atmosphere during the conversion process, although a recent study in Malaysia suggests that organic matter content declines within the first one to two years following the start of conversion (Tonks et al., 2017). Furthermore, the conversion altered the surface peat functional organic chemistry as carbohydrates were preferentially depleted as a result of aerobic decay suggesting that conversion will enhance peat recalcitrance but increase its aromaticity (Tonks et al., 2017; Yule et al., 2018).

In addition to land use conversion, tropical peatlands are also affected by climate change which is predicted to result in a $3-7^{\circ} \mathrm{C}$ increase in temperature and increased seasonality of rainfall, resulting in more pronounced dry and wet seasons (add reference). The impacts of this include increasing length of periods of flooded conditions and above the surface water-tables (IPCC, 2007). Recent work in pristine peatlands in the Neotropics has shown strong temperature responses of GHGs emissions under high water-table conditions for both $\mathrm{CO}_{2}$ and $\mathrm{CH}_{4}$ (Sjogersten et al., 2018). However, both aerobic and anaerobic temperature responses of GHG emissions from wetland soils differ considerably among land use types, likely in response to 
Cooper, H., Vane, C.H., Evers, S., Aplin, P., Girkin, N., Sjogersten, S. 2019. From peat swamp forest to oil palm plantations: the stability of tropical peatland carbon. Geoderma 342, 109-117 https://doi.org/10.1016/j.geoderma.2019.02.021

102

103

differences in organic matter lability (Dunfield et al., 1993; Inglett et al., 2012; Turetsky et al., 2014; Gritsch et al., 2015; Duval and Radu 2018). As deforestation rates in Southeast Asia show no signs of slowing, PSFs are predicted to be extinct by 2050 , if current rates of deforestation of peatlands continue unchecked (Miettinen et al., 2016). It is therefore critical that we quantify the climate feedback potentials from bothPSF and also degraded peats in plantations. Indeed, it is plausible that high temperatures may further increase the climate burden of GHG emissions from oil palm plantations as the temperature sensitivity of organic matter decomposition is predicted to increase with recalcitrance according to kinetic theory (Bosatta and Ågren, 1999; Davidson and Janssens, 2006).

As a result of knowledge gaps outlined above, GHG emissions from drained tropical peatland conversion are at present overlooked in GHG emission budgets as considered by the UN Framework Convention on Climate Change (Climate Change 2014 Synthesis Report for Policymakers, 2014; IPCC, 2006). However, given their important role in the global carbon cycle and the pressures they are exposed to from both land use and climate change it is vital to develop mechanistic understanding of the controls of GHG emissions from forested and converted peatlands to underpin the delivery of evidence based sustainable land use management and policy (Evers et al., 2017). Therefore, this study aims to improve our understanding of the impact of anthropogenic activities e.g. drainage and deforestation on soil organic matter stability and subsequent GHG fluxes from tropical peatlands. To achieve this the study addresses the three specific hypothesis linked to how land use change and temperature alter peat lability and $\mathrm{CO}_{2}$ and $\mathrm{CH}_{4}$ fluxes: Our first hypothesis (1) "land conversion of drainage based oil palm plantation result in depletion of labile substrates in surface peat affected by drainage but not in deeper peat layers" is based on the notion that drainage promotes aerobic decomposition in surface peat but not in deeper peats below the water-table where anoxic 
Cooper, H., Vane, C.H., Evers, S., Aplin, P., Girkin, N., Sjogersten, S. 2019. From peat swamp forest to oil palm plantations: the stability of tropical peatland carbon. Geoderma 342, 109-117 https://doi.org/10.1016/j.geoderma.2019.02.021

conditions remain (Jauhiainen et al., 2005; Couwenberg et al., 2010). Because substrate lability often is a predictor of GHG emissions in tropical peatlands (Wright et al., 2011; HoyosSantillan et al., 2016) we hypothesised that (2) "ex situ anaerobic $\mathrm{CO}_{2}$ and $\mathrm{CH}_{4}$ production will be lower in the later stages of land conversion to oil palm plantation as a result of depletion of labile carbon”. In line with kinetic theory (Bosatta and Agern 1999; Davidson and Janssens 2006) we also hypothesised that (3) "the impact of substrate depletion on GHG production is exacerbated by higher temperatures with the strongest impact in surface peat".

\section{Methods}

\subsection{Study Sites}

This study was conducted in November-December 2014 in North Selangor Peat Swamp Forest (NSPSF), Malaysia. The NSPSF comprises of Raja Musa Forest Reserve, Sungai Karang Forest Reserve, Sungai Dusun Wildlife Reserve and part of Bukit Belata Forest Reserve Extension and covers an area of 81, 304 ha. The central area of the reserve is secondary mixed forest; the majority of the area was logged from the $19^{\text {th }}$ century up until the 1980 's, and a significant area of the northern edge of the reserve has already undergone oil palm conversion (Kumari, 1996). Four land conversion classes were selected, with five replicate sites for each, to represent the stages involved in the process of conversion (ranging from secondary forest to mature oil palm), shown in figure 1 . The forest sites chosen for this study had not been targeted for logging for approximately 40 years, as a result the forest sites were in areas of high canopy density (trees $>25$ m, canopy coverage $>80 \%$ (Global Environment Centre, 2014).

Drained sites comprised a similar forest structure but large drainage ditches (2-3 m wide and ca. $2 \mathrm{~m}$ deep) had been dug every few hundred meters, six months prior to sampling, to lower 
Cooper, H., Vane, C.H., Evers, S., Aplin, P., Girkin, N., Sjogersten, S. 2019. From peat swamp forest to oil palm plantations: the stability of tropical peatland carbon. Geoderma 342, 109-117 https://doi.org/10.1016/j.geoderma.2019.02.021

Parartocarpus venenosus, Ixora grandiflora, Pternandra galeata; ferns: Stenoclaena palustris, Asplenium longissimum, Nephrolepsis biserrata; palm: Crytostachys sp.; sedges: Cyperus rotundus and abundant stands of Pandanus atrocarpus (Yule and Gomez, 2009).

154 Recently planted young oil palm sites, where both deforestation and artificial lowering of the months prior to sampling. ca. 10-15 years old. Mature oil palm sites had been subject to deforestation of the PSF and drained before seedlings were planted.
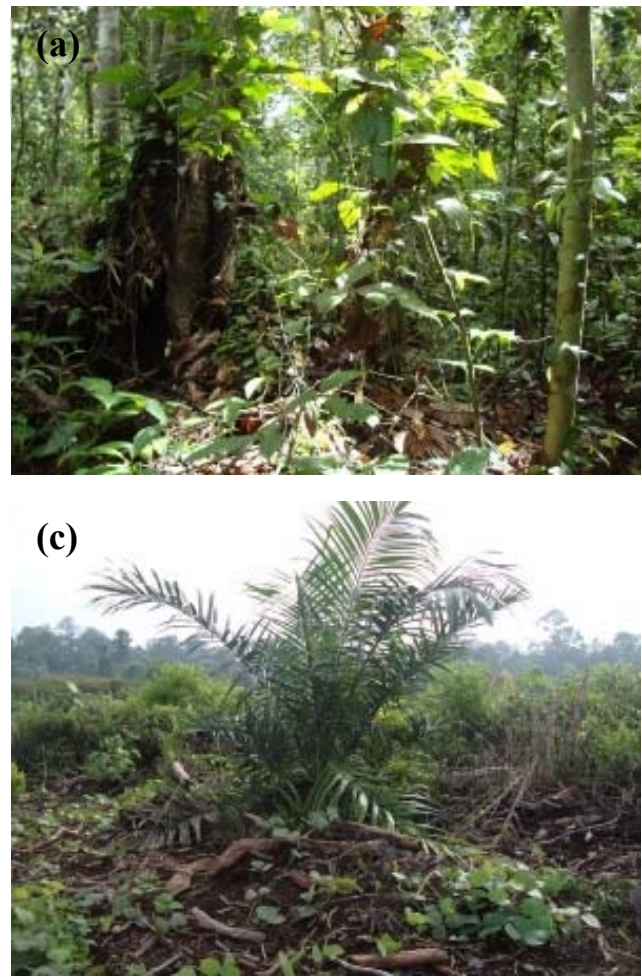
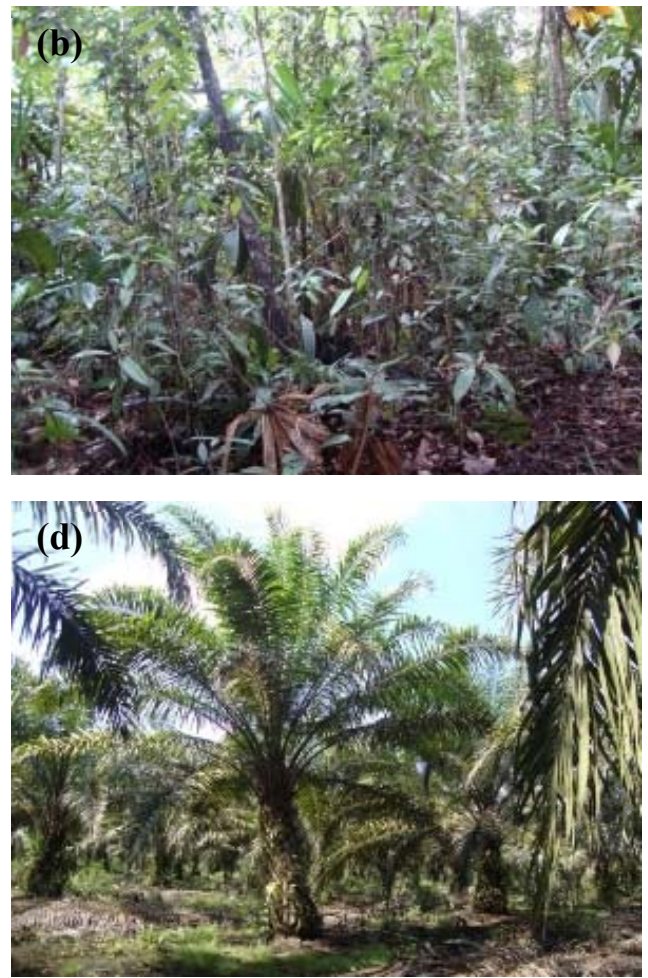
Cooper, H., Vane, C.H., Evers, S., Aplin, P., Girkin, N., Sjogersten, S. 2019. From peat swamp forest to oil palm plantations: the stability of tropical peatland carbon. Geoderma 342, 109-117 https://doi.org/10.1016/j.geoderma.2019.02.021

Figure 1. Type of peatland habitats surveyed (a) secondary PSF, (b) drained secondary PSF,

(c) six-month oil palm plantation and (d) mature oil palm plantation.

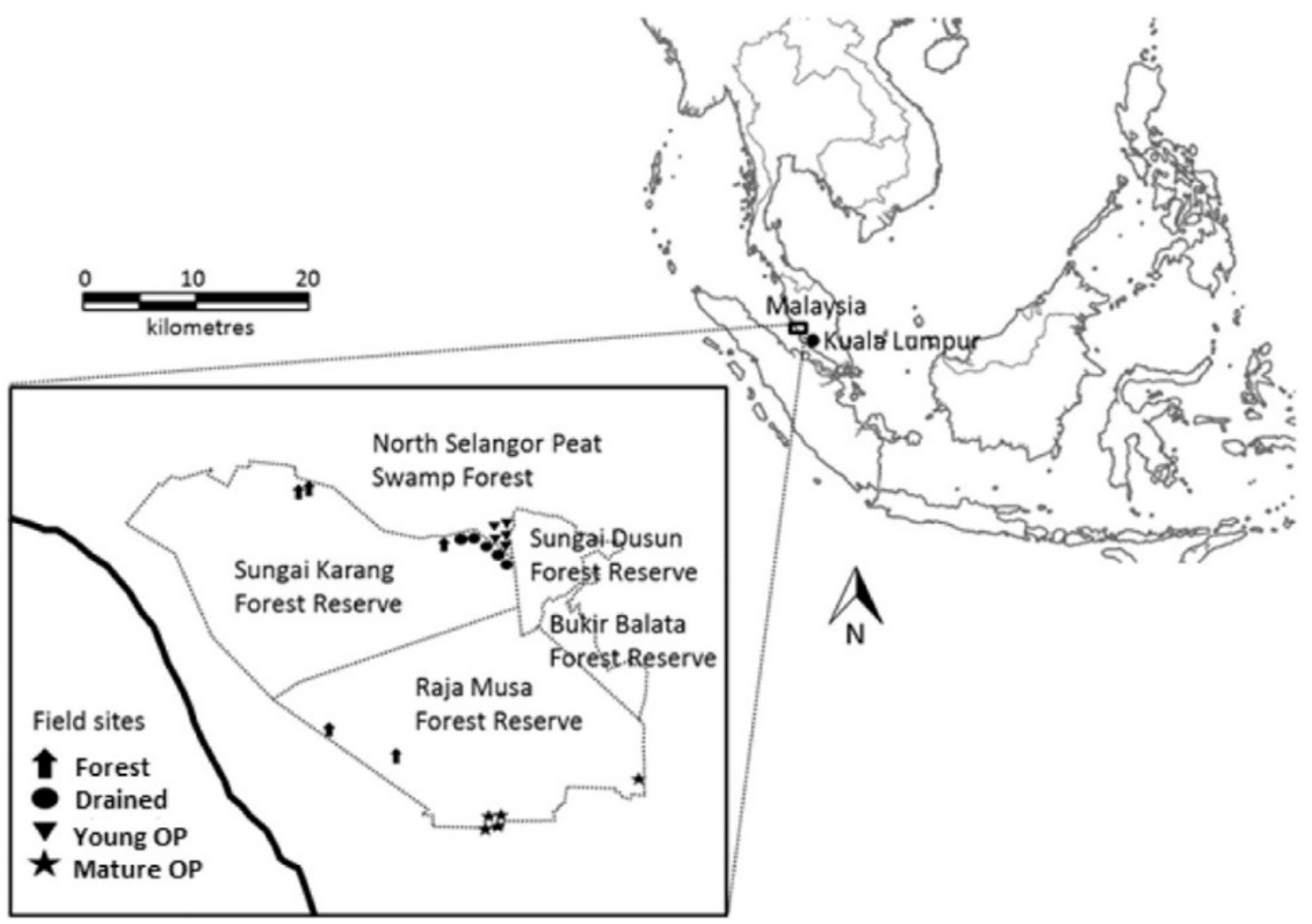

180

Figure 2. Location of North Selangor Peat Swamp Forest and the sites belonging to the four

different conversion stages. Forest, drained, recently planted and mature oil palm plantation sites.

\subsection{Field sampling}

185 In total, four land conversion stages and five plots with an area of $900 \mathrm{~m}^{2}$ were marked out.

186 Forest and mature oil palm areas were chosen to maximise spatial distribution, taking into account access, and based on areal images and maps. Drained and recently planted oil palm plantation sites were constrained to two areas due to land management. 
Cooper, H., Vane, C.H., Evers, S., Aplin, P., Girkin, N., Sjogersten, S. 2019. From peat swamp forest to oil palm plantations: the stability of tropical peatland carbon. Geoderma 342, 109-117 https://doi.org/10.1016/j.geoderma.2019.02.021

189

190

191

192

193

194

195

196

197

198

199

200

201

202

203

204

205

206

207

208

209

At all sites, random number tables were used to determine the direction and distance from the south west corner of the plot to ensure random sampling within each plot. GPS coordinates were recorded for each corner and provided in Supplementary Information 1.

In each of the plots, peat samples were taken from depths $0-5 \mathrm{~cm}$ and $50-55 \mathrm{~cm}$ that covered mostly oxic, waterlogged and anoxic conditions respectively. Samples were extracted using a side-filling Russian Peat Corer (Van Walt, UK), with a $50 \mathrm{~cm}$ long sampling chamber. Immediately following extraction, peat samples were bagged and sealed to avoid moisture loss.

\subsection{Peat physical properties}

Peat water content, bulk density and organic matter content were determined for all samples. Volumetric water content was estimated from the field using a Delta-T Theta Probe. Measurements were recorded three times per plot to provide an average. Gravimetric water content was assessed by oven drying the peat at $105{ }^{\circ} \mathrm{C}$ for 48 hours. Organic matter content was determined as the mass lost after ignition for $7 \mathrm{~h}$ at $550^{\circ} \mathrm{C}$ and bulk density was determined using oven dried mass methods and known volumes.

\subsection{Laboratory Incubations}

Samples were transported from North Selangor to University of Nottingham and frozen immediately until analysis. At time of incubation, samples were taken from the freezer and left to defrost in a cold room $\left(4^{\circ} \mathrm{C}\right)$ before sub-sampling and subsequent incubation at two temperatures, i) $25^{\circ} \mathrm{C}$ and anaerobic and ii) $30^{\circ} \mathrm{C}$ and anaerobic. 
Cooper, H., Vane, C.H., Evers, S., Aplin, P., Girkin, N., Sjogersten, S. 2019. From peat swamp forest to oil palm plantations: the stability of tropical peatland carbon. Geoderma 342, 109-117 https://doi.org/10.1016/j.geoderma.2019.02.021

210 Prior to incubation, $3 \mathrm{~g}$ of dry weight equivalent peat samples were placed in $125 \mathrm{ml}$ serum bottles ( 80 in total) and flooded with $1 \mathrm{~cm}^{3}$ of water. Serum bottles were flushed with nitrogen for two minutes to displace oxygen and create anaerobic conditions before sealing with a rubber septa (13 x 19 x 12 mm; Rubber B.V., Hilversum, NL), and an aluminium crimp top. Serum bottles were placed in either $25^{\circ} \mathrm{C}$ or $30^{\circ} \mathrm{C}$ temperature control room to replicate ambient and elevated soil conditions.

After seven days to allow the microbial community to establish, serum bottles were opened to the air to dissipate accumulated headspace gases and then flushed with nitrogen for two minutes and re-sealed. Following an additional seven days of incubation, headspace gas samples $(5 \mathrm{ml})$ were collected weekly by syringe from each serum bottle and analysed immediately by gas chromatography (GC-2014, Shimadzu UK LTD, Milton Keynes, UK) over four weeks.

$\mathrm{CO}_{2}$ and $\mathrm{CH}_{4}$ concentration were analysed using a single injection system, with a $1 \mathrm{ml}$ sample loop that passed the gas sample using $\mathrm{N}_{2}$ as a carrier. Thermal conductivity detectors (TCD) and a flame ionization detectors (FID), were used to measure $\mathrm{CO}_{2}$ and $\mathrm{CH}_{4}$ respectively.

The fluxes were calculated using linear regression of the gas concentration against time. The greenhouse gas data was converted to mass per volume and mass per weight basis by the use of the ideal gas equation and the molecular mass of each gas as shown in Eq. (1). From this, the gas flux from each incubation was calculated using Eq. (2).

229 Where $P$ is the atmospheric pressure $(\approx 1 \mathrm{~atm}), V$ is the volume of headspace $\left(\mathrm{dm}^{-3}\right), n$ is the number of moles of gas, $R$ is the ideal gas constant $\left(0.08205746 \mathrm{~L} \mathrm{~atm} \mathrm{~K}^{-1} \mathrm{~mol}^{-1}\right)$, and $T$ is temperature $\left(273.15+\right.$ room temperature in $\left.{ }^{\circ} \mathrm{C}\right)$. 
Cooper, H., Vane, C.H., Evers, S., Aplin, P., Girkin, N., Sjogersten, S. 2019. From peat swamp forest to oil palm plantations: the stability of tropical peatland carbon. Geoderma 342, 109-117 https://doi.org/10.1016/j.geoderma.2019.02.021

$233 E=\left(\frac{n m}{a t}\right) \times 1000$

234 Where $E$ is the flux of each gas $\left(\mathrm{mg} \mathrm{m}^{-2} \mathrm{~h}^{-1}\right), n$ is the number of moles $\left(\mathrm{CO}_{2}\right.$ or $\left.\mathrm{CH}_{4}\right), m$ is the 235 molar weight $\left(\mathrm{CO}_{2}: 44.01\right.$ and $\left.\mathrm{CH}_{4}: 16.04\right), a$ is the area of soil core used and $t$ is the time in 236 the hour.

Rock-Eval 6 Pyrolysis

Surface and subsurface peat samples were analysed using a Rock-Eval 6 analyser. Freeze-dried powdered peat samples $(60 \mathrm{mg})$ were heated at $300{ }^{\circ} \mathrm{C}$ for three minutes before an increase in temperature to $650{ }^{\circ} \mathrm{C}$ at a rate of $25^{\circ} \mathrm{C}$ per minute in an inert $\mathrm{N}_{2}$ atmosphere. Residual carbon was subsequently oxidized from $300{ }^{\circ} \mathrm{C}$ to $850{ }^{\circ} \mathrm{C}$ at a rate of $20^{\circ} \mathrm{C}$ per minute. The release of hydrocarbons during the two-stage pyrolysis process was detected by a flame ionisation detector, with an infrared cell detecting the release of $\mathrm{CO}$ and $\mathrm{CO}_{2}$ during the thermal cracking of the organic matter. Rock-Eval analysis generated a range of standard parameters including S1 (a measure of free hydrocarbons released on heating to $300^{\circ} \mathrm{C}$ ), S2 (hydrocarbons released on the thermal cracking of organic matter for temperatures up to $850^{\circ} \mathrm{C}$ ), $\mathrm{S} 3 \mathrm{CO}$ and $\mathrm{S} 3 \mathrm{CO}_{2}$ (the $\mathrm{CO}$ and $\mathrm{CO}_{2}$ yielded from the breakdown of kerogen), TpkS2 (the temperature associated with the highest yield of bound hydrocarbons) and total organic carbon ( $\mathrm{TOC}_{\mathrm{RE}}$ ).

The Hydrogen Index (HI), a measure of hydrocarbons released relative to TOC was calculated from S2 $\times 100 / \mathrm{TOC}_{\mathrm{RE}}$. The Oxygen Index (OI), corresponding to the amount of oxygen released as $\mathrm{CO}$ and $\mathrm{CO}_{2}$ relative to $\mathrm{TOC}$ RE was calculated from $\mathrm{S} 3 \times 100 / \mathrm{TOC}$ RE.

Additional parameters were calculated from the deconvolution of S2 pyrograms using Fityk v0.9.7, a curve fitting and data analysis program. S2 pyrograms were deconvoluted into six previously been attributed to organic compounds of increasing complexity and recalcitrance 
Cooper, H., Vane, C.H., Evers, S., Aplin, P., Girkin, N., Sjogersten, S. 2019. From peat swamp forest to oil palm plantations: the stability of tropical peatland carbon. Geoderma 342, 109-117 https://doi.org/10.1016/j.geoderma.2019.02.021

256 (Disnar et al., 2003; Sebag et al., 2006). F1 signals represent high labile fresh plant material 257 including simple polysaccharides. F2 signals correspond to lignin and cellulose derived 258 compounds, and F3 and F4 relate to increasingly humified macromolecules. F5 and F6 signals 259 can be attributed to the presence of highly mature and recalcitrant soil organic matter, or charcoal. These signals were used to develop an additional sets of indices. Saenger et al. (2013) 
Cooper, H., Vane, C.H., Evers, S., Aplin, P., Girkin, N., Sjogersten, S. 2019. From peat swamp forest to oil palm plantations: the stability of tropical peatland carbon. Geoderma 342, 109-117 https://doi.org/10.1016/j.geoderma.2019.02.021

261

262

proposed combining these signals into three categories representing different phases of carbon thermal stability. $\mathrm{C}_{1}$ represents the highly labile hydrocarbon compounds (F1 and F2), $\mathrm{C}_{\mathrm{i}}$ (corresponding to the more stabilised soil carbon pool, F3), and the highly recalcitrant passive pool, $\mathrm{C}_{\mathrm{p}}(\mathrm{F} 4-\mathrm{F} 6)$ (Saenger et al., 2013).

\subsection{Statistical Analysis}

Differences in Rock-Eval parameters and indices were assessed using linear mixed effects model fitted using Residual Maximum Likelihood (REML) to account for variable dependence between sampling plots. Conversion class and depth were selected as fixed effects and sites as random effects. Rates of $\mathrm{CH}_{4}$ and $\mathrm{CO}_{2}$, proportion of carbon in $\mathrm{Cl}_{1}, \mathrm{C}_{\mathrm{i}}$ and $\mathrm{C}_{\mathrm{p}}$, and total organic carbon were log-transformed to meet assumptions of normality and were also assessed using REML. Relationships between Rock-Eval parameters and $\mathrm{CH}_{4}$ and $\mathrm{CO}_{2}$ fluxes from different land uses and depths were assessed using Principal Component Analysis (PCA), based on correlation matrices. All statistical analyse were conducted in GenStat (v17.07

\section{Results}

\subsection{Rock-Eval Pyrolysis}

Thermolabile hydrocarbons (S1), which are released on heating at $300{ }^{\circ} \mathrm{C}$ were significantly different between land uses in surface peats $\left(\mathrm{F}_{3,32}=7.79, \mathrm{P}<0.001\right.$, Table 2$)$, with the highest concentrations measured at drained sites, followed by recently planted, forest and mature oil palm plantations (Table 1). More recalcitrant hydrocarbons (S2) which are released between $300-650{ }^{\circ} \mathrm{C}$ (Johannes et al., 2006), also significantly differed in surface peats between land uses $\left(\mathrm{F}_{3,32}=5.45, \mathrm{p}<0.05\right.$, Table 2$)$ and demonstrated a similar pattern as $\mathrm{S} 1$ values, with the 
Cooper, H., Vane, C.H., Evers, S., Aplin, P., Girkin, N., Sjogersten, S. 2019. From peat swamp forest to oil palm plantations: the stability of tropical peatland carbon. Geoderma 342, 109-117 https://doi.org/10.1016/j.geoderma.2019.02.021

highest values measured in drained sites and the lowest in mature oil palm plantations (Table $1)$.

TpkS2, which corresponds to the temperature at which hydrocarbon compound release in maximised (Disnar, 1994; Espitalié et al., 1985), showed an increase with land conversion towards oil palm plantations. The lower TpkS2 values in forest and drained sites (403 and 416 ${ }^{\circ} \mathrm{C}$ respectively) are characteristic of the thermal breakdown of more labile polysaccharides and lignins. In contrast, values over $420^{\circ} \mathrm{C}$, as measured in recently planted and mature oil palm sites ( 425 and $441^{\circ} \mathrm{C}$ respectively), are typical of increasingly immature humic substances (Disnar et al., 2003). TOC was high and showed little variation between forest, drained and recently planted sites (ranging from $45 \%$ to $47 \%$ ), however TOC was significantly lower in the mature oil palm sites with $37 \%$ (Table 1) $\left(\mathrm{F}_{3,32}=2.92, \mathrm{p}<0.05\right.$, Table 2$)$.

Table 1. Selected Rock-Eval 6 parameters in surface and subsurface peats. Means \pm one SEM.

\begin{tabular}{|c|c|c|c|c|c|}
\hline Parameter & Peat Depth & Forest & Drained & Recently Planted & $\begin{array}{l}\text { Mature Oil } \\
\text { Palm }\end{array}$ \\
\hline \multirow[t]{2}{*}{ S1 $\left(\mathrm{mg} \mathrm{g}^{-1}\right)$} & Surface & $27.87 \pm 1.17$ & $34.89 \pm 2.23$ & $28.76 \pm 1.91$ & $19.91 \pm 1.58$ \\
\hline & Subsurface & $20.33 \pm 3.59$ & $31.54 \pm 3.1$ & $28.55 \pm 1.52$ & $25.34 \pm 3.12$ \\
\hline \multirow[t]{2}{*}{$\mathrm{S} 2\left(\mathrm{mg} \mathrm{g}^{-1}\right)$} & Surface & $127.26 \pm 17.04$ & $145.26 \pm 9.04$ & $135.68 \pm 5.98$ & $92.88 \pm 8.53$ \\
\hline & Subsurface & $125.95 \pm 12.52$ & $149.44 \pm 9.25$ & $130.71 \pm 3.54$ & $113.68 \pm 16.00$ \\
\hline \multirow[t]{2}{*}{ TpkS2 $\left({ }^{\circ} \mathrm{C}\right)$} & Surface & $403.8 \pm 13.06$ & $416.8 \pm 10.81$ & $425.4 \pm 2.46$ & $441.6 \pm 6.12$ \\
\hline & Subsurface & $406.8 \pm 14.12$ & $423.6 \pm 1.25$ & $422.4 \pm 3.52$ & $427.6 \pm 8.00$ \\
\hline \multirow[t]{2}{*}{ TOCRE $(\%)$} & Surface & $45.21 \pm 1.64$ & $46.48 \pm 2.13$ & $47.37 \pm 1.05$ & $37.51 \pm 3.96$ \\
\hline & Subsurface & $45.21 \pm 2.15$ & $47.77 \pm 0.71$ & $47.54 \pm 0.61$ & $43.45 \pm 5.20$ \\
\hline \multirow{2}{*}{$\begin{array}{l}\text { HI (mg HC g-1 } \\
\text { TOC RE6) }\end{array}$} & Surface & $279.2 \pm 29.38$ & $312.4 \pm 13.43$ & $286.8 \pm 12.75$ & $252.6 \pm 19.3$ \\
\hline & Subsurface & $277.8 \pm 21.66$ & $313.4 \pm 21.35$ & $275.2 \pm 6.09$ & $263.8 \pm 21.15$ \\
\hline $\begin{array}{l}\text { OI }\left(\mathrm{mg} \mathrm{O} \mathrm{O}_{2} \mathrm{~g}^{-1}\right. \\
\text { TOC } \\
\text { RE6 })\end{array}$ & Surface & $180 \pm 16.37$ & $138.6 \pm 16.00$ & $132.8 \pm 2.52$ & $160.2 \pm 6.94$ \\
\hline
\end{tabular}


Cooper, H., Vane, C.H., Evers, S., Aplin, P., Girkin, N., Sjogersten, S. 2019. From peat swamp forest to oil palm plantations: the stability of tropical peatland carbon. Geoderma 342, 109-117 https://doi.org/10.1016/j.geoderma.2019.02.021 
Cooper, H., Vane, C.H., Evers, S., Aplin, P., Girkin, N., Sjogersten, S. 2019. From peat swamp forest to oil palm plantations: the stability of tropical peatland carbon. Geoderma 342, 109-117 https://doi.org/10.1016/j.geoderma.2019.02.021

Table 2: Rock-Eval 6 statistics assessed via linear mixed effects model (REML). Significant differences in italics.

\begin{tabular}{|c|c|c|c|c|c|c|c|c|c|c|c|c|}
\hline & \multicolumn{3}{|l|}{ Land use } & \multicolumn{3}{|c|}{ Depth } & \multicolumn{6}{|c|}{ Land use*Depth } \\
\hline & F-statistic & d.f. & $\mathbf{p}$ & SED & F-statistic & d.f. & $\mathbf{p}$ & SED & F-statistic & d.f. & $\mathbf{p}$ & SED \\
\hline S1 $\left(\mathrm{mg} \mathrm{g}^{-1}\right)$ & 7.79 & 3,32 & $<0.001$ & 3.43 & 0.68 & 1,32 & 0.41 & 3.43 & 2.53 & 3,32 & 0.074 & 4.86 \\
\hline $\mathrm{S} 2\left(\mathrm{mg} \mathrm{g}^{-1}\right)$ & 5.45 & 3,32 & 0.004 & 15.7 & 0.33 & 1,32 & 0.557 & 15.7 & 0.52 & 3,32 & 0.669 & 22.3 \\
\hline $\operatorname{S3CO}\left(\mathrm{mg} \mathrm{g}^{-1}\right)$ & 1.47 & 3,32 & 0.242 & 4.48 & 1.35 & 1,32 & 0.254 & 4.48 & 0.35 & 3,32 & 0.791 & 6.34 \\
\hline $\mathrm{S} \mathrm{CO}_{2}\left(\mathrm{mg} \mathrm{g}^{-1}\right)$ & 0.46 & 3,32 & 0.712 & 2.62 & 1.54 & 1,32 & 0.223 & 2.62 & 0.07 & 3,32 & 0.976 & 3.7 \\
\hline $\mathbf{T}_{\text {peak }}\left({ }^{\circ} \mathrm{C}\right)$ & 3.85 & 3,32 & 0.018 & 12.34 & 0.09 & 1,32 & 0.772 & 12.34 & 0.54 & 3,32 & 0.658 & 17.46 \\
\hline TOC $_{\text {RE }}(\%)$ & 2.92 & 3,32 & 0.049 & 3.7 & 0.91 & 1,32 & 0.332 & 3.7 & 0.55 & 3,32 & 0.653 & 5.3 \\
\hline HI & 2.73 & 3,32 & 0.060 & 27.38 & 0.0 & 1,32 & 0.988 & 27.38 & 0.12 & 3,32 & 0.950 & 38.72 \\
\hline OI & 2.73 & 3,32 & 0.060 & 18.1 & 3.13 & 1,32 & 0.087 & 18.1 & 0.81 & 3,32 & 0.496 & 25.60 \\
\hline
\end{tabular}


Cooper, H., Vane, C.H., Evers, S., Aplin, P., Girkin, N., Sjogersten, S. 2019. From peat swamp forest to oil palm plantations: the stability of tropical peatland carbon. Geoderma 342, 109-117 https://doi.org/10.1016/j.geoderma.2019.02.021 
Cooper, H., Vane, C.H., Evers, S., Aplin, P., Girkin, N., Sjogersten, S. 2019. From peat swamp forest to oil palm plantations: the stability of tropical peatland carbon. Geoderma 342, 109-117 https://doi.org/10.1016/j.geoderma.2019.02.021

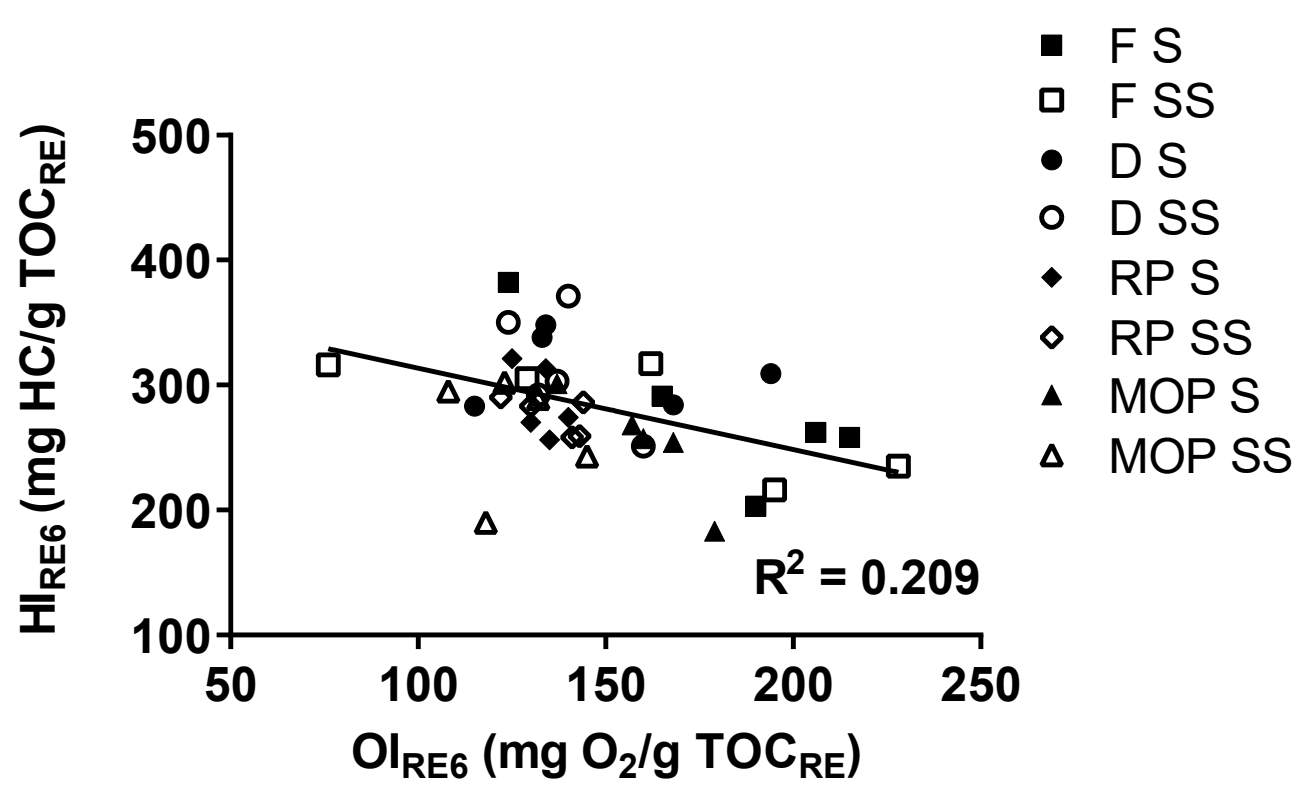

Figure 3. Pseudo-Van Krevelen linking changes against $\mathrm{HI}$ and $\mathrm{OI}$ for all land uses in surface (S) and subsurface samples (SS) showing trends in humification.

In surface peats, $\mathrm{HI}$ decreased from $312 \mathrm{mg} \mathrm{HC} \mathrm{g}^{-1} \mathrm{TOC}_{\mathrm{RE} 6}$ at the drained sites to $252 \mathrm{mg} \mathrm{HC}$ $\mathrm{g}^{-1}$ TOCRE6 in mature oil palm sites, while OI increased from $180 \mathrm{O}_{2} \mathrm{~g}^{-1} \mathrm{TOC}_{\mathrm{RE}}$ in the forest sites to $132 \mathrm{mg} \mathrm{O}_{2} \mathrm{~g}^{-1} \mathrm{TOC}_{\mathrm{RE} 6}$ in the recently planted sites (Table 2). In forest and drained sites, HI was higher in the subsurface compared to surface peats, and similarly with OI, higher concentrations were measured in forest, drained and recently planted sites in the subsurface peats.

There was large variation $\left(\mathrm{F}_{3,32}=2.73, \mathrm{p}=0.06\right.$, Table 2$)$, in $\mathrm{HI}$ and $\mathrm{OI}$ in surface peats at forest and drained sites compared to later conversion stages in recently planted and mature oil palm plantations which clustered closer together (Fig. 3). 
Cooper, H., Vane, C.H., Evers, S., Aplin, P., Girkin, N., Sjogersten, S. 2019. From peat swamp forest to oil palm plantations: the stability of tropical peatland carbon. Geoderma 342, 109-117 https://doi.org/10.1016/j.geoderma.2019.02.021

\subsection{SOM Thermostability}

In surface peats at forest, drained and recently planted sites, the labile carbon pool $\left(\mathrm{C}_{1}\right)$ was the largest of the three pools, accounting for $69 \%, 61 \%$ and 50\% respectively (Fig. 4). In contrast, $\mathrm{C}_{1}$ significantly differed in mature oil palm sites from the other land uses $\left(\mathrm{F}_{3,16}=3.41, \mathrm{P}<0.05\right.$, Table 3) and accounted for only $15 \%$ of carbon. A similar trend was observed in sub surface peats in the $\mathrm{C}_{1}$ pool, with a decrease in lability with conversion stages, although not significant peats $\left(\mathrm{F}_{3,16}=0.04, \mathrm{P}=0.84\right.$, Table 3$)$. The intermediate carbon pool $\left(\mathrm{C}_{\mathrm{i}}\right)$ varied significantly in surface peats $\left(\mathrm{F}_{3,16}=3.83, \mathrm{P}<0.05\right.$, Table 3$)$ with mature oil palms sites having the largest contribution in this pool of $67 \%$ (Fig. 4). The passive pool $\left(\mathrm{C}_{\mathrm{p}}\right)$ differed significantly between sites in the surface peats $\left(\mathrm{F}_{3,16}=4.58, \mathrm{P}<0.05\right.$, Table 3$)$ with the highest contribution at drained sites and the lowest in forest sites (29\% and 5\% respectively). 
Cooper, H., Vane, C.H., Evers, S., Aplin, P., Girkin, N., Sjogersten, S. 2019. From peat swamp forest to oil palm plantations: the stability of tropical peatland carbon. Geoderma 342, 109-117 https://doi.org/10.1016/j.geoderma.2019.02.021
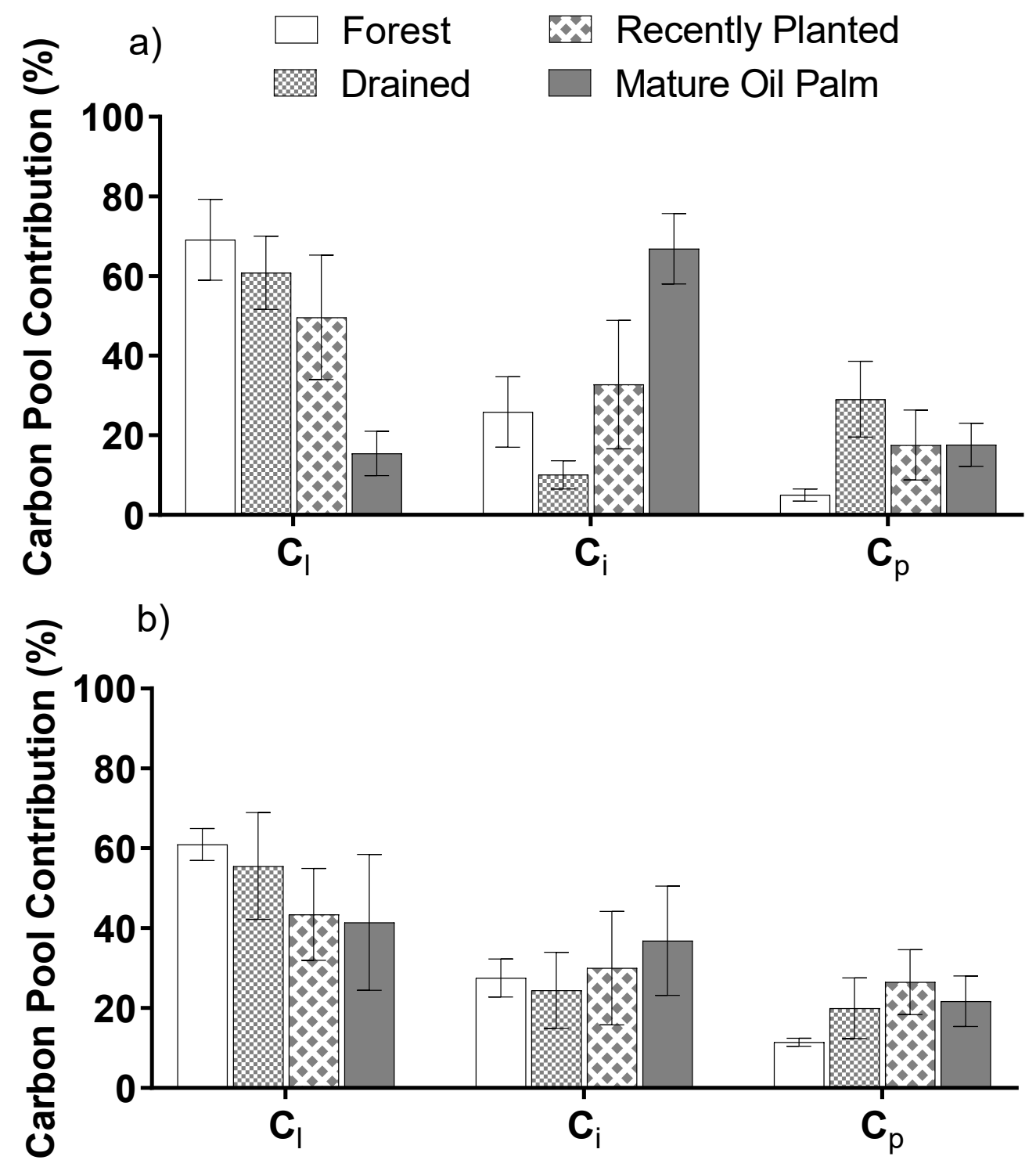

Figure 4. Proportions of labile $\left(\mathrm{C}_{1}\right)$, intermediate $\left(\mathrm{C}_{\mathrm{i}}\right)$ and passive $\left(\mathrm{C}_{\mathrm{p}}\right)$ carbon pools for different sites in a) surface and b) subsurface peats. Means \pm one SEM. $\mathrm{n}=5$. 
Cooper, H., Vane, C.H., Evers, S., Aplin, P., Girkin, N., Sjogersten, S. 2019. From peat swamp forest to oil palm plantations: the stability of tropical peatland carbon. Geoderma 342, 109-117 https://doi.org/10.1016/j.geoderma.2019.02.021

Table 3: Carbon pools, measured through deconvolution of pyrograms produced by Rock-Eval 6, statistics assessed via linear mixed effects model (REML). Significant differences in italics.

\begin{tabular}{|c|c|c|c|c|c|c|c|c|c|c|c|c|}
\hline & \multicolumn{4}{|l|}{ Land use } & \multicolumn{4}{|l|}{ Depth } & \multicolumn{4}{|c|}{ Land use* Depth } \\
\hline & F-statistic & d.f. & $\mathbf{p}$ & SED & F-statistic & d.f. & $\mathbf{p}$ & SED & F-statistic & d.f. & $\mathbf{p}$ & SED \\
\hline $\mathbf{C}_{1}$ & 3.41 & 3,16 & 0.04 & 16.4 & 0.04 & 1,16 & 0.84 & 15.4 & 1.11 & 3,16 & 0.34 & 21.9 \\
\hline $\mathbf{C}_{\mathbf{i}}$ & 3.83 & 3,16 & 0.03 & 15.3 & 0.29 & 1,16 & 0.6 & 15.6 & 1.44 & 3,16 & 0.27 & 22.1 \\
\hline$C_{p}$ & 4.58 & 3,16 & 0.017 & 9.6 & 0.19 & 1,16 & 0.67 & 11.8 & 0.47 & 3,16 & 0.71 & 16.6 \\
\hline
\end{tabular}

\section{3 $\mathrm{CO}_{2}$ and $\mathrm{CH}_{4}$ Incubations}

Peats incubated at $25^{\circ} \mathrm{C}$ and $30^{\circ} \mathrm{C}$ exhibited a significant declining trend with conversion in surface samples $\left(\mathrm{F}_{3,16}=9.4, \mathrm{p}<0.001\right.$, Table 4), with a similar pattern, although less pronounced, in subsurface peats (Fig. 5). Peats incubated at $30^{\circ} \mathrm{C}$ had significantly higher $\mathrm{CO}_{2}$ fluxes across all land uses $\left(\mathrm{F}_{1,48}=35.1, \mathrm{p}<0.001\right.$, Table 4$)$ when compared to peats incubated at $25^{\circ} \mathrm{C}$ with the highest mean fluxes from forest peats, with an average of $5.2 \mathrm{ug} \mathrm{g}^{-1} \mathrm{~h}^{-1}$ from peats incubated at $25^{\circ} \mathrm{C}$ and $9.1 \mathrm{ug} \mathrm{g}^{-1} \mathrm{~h}^{-1}$ from peats incubated at $30{ }^{\circ} \mathrm{C}$.

$\mathrm{CH}_{4}$ fluxes were significantly higher in forest and drained sites compared to recently planted and mature oil palm plantations in surface peats $\left(F_{3,16}=9.4, p<0.001\right.$, Table 4$)$, with a less pronounced difference with depth from the recently planted and mature oil palm sites. 
Cooper, H., Vane, C.H., Evers, S., Aplin, P., Girkin, N., Sjogersten, S. 2019. From peat swamp forest to oil palm plantations: the stability of tropical peatland carbon. Geoderma 342, 109-117 https://doi.org/10.1016/j.geoderma.2019.02.021

a)

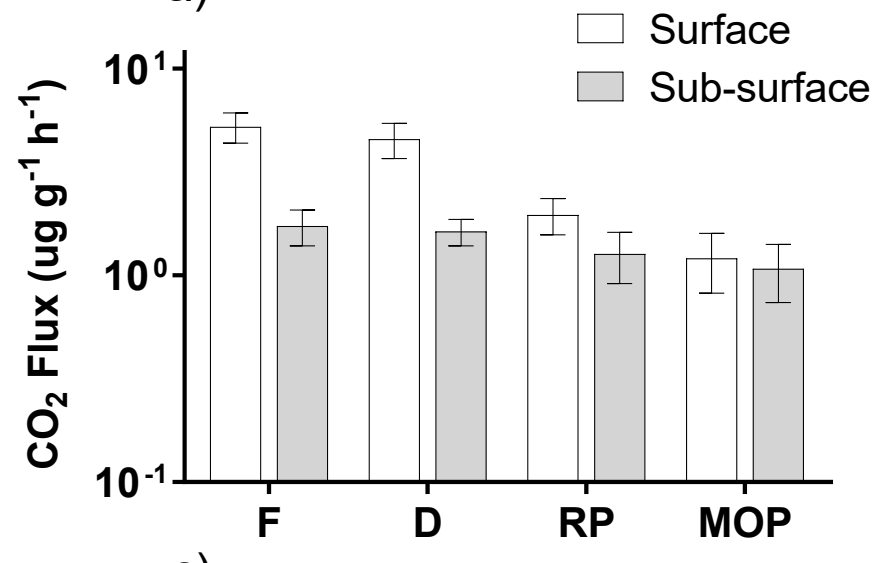

c)

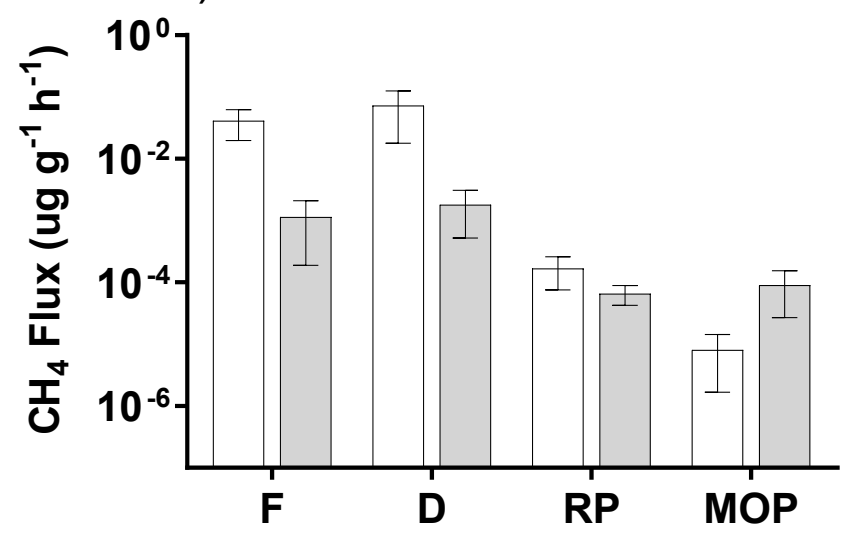

b)
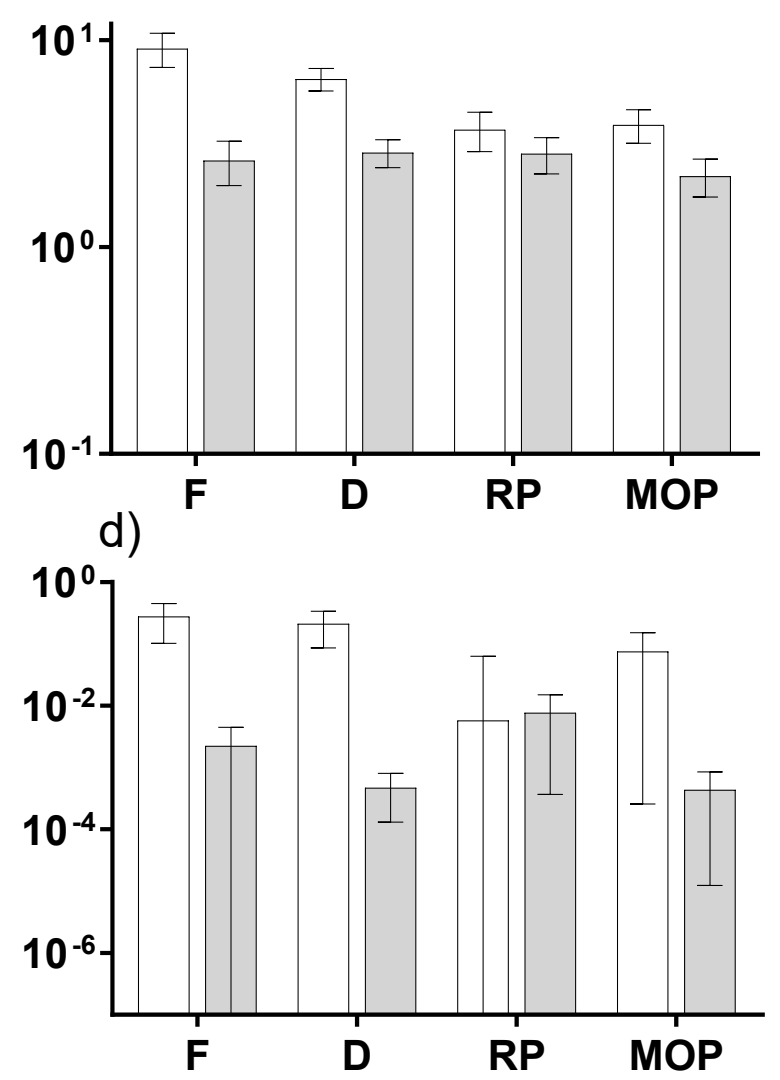

Figure 5. Logged carbon dioxide (a\&b) and logged methane fluxes (c\&d) at $25^{\circ} \mathrm{C}(\mathrm{a} \& \mathrm{c})$ and $30^{\circ} \mathrm{C}(\mathrm{b} \& \mathrm{~d})$ from surface $(0-5 \mathrm{~cm})$ and subsurface $(50-55 \mathrm{~cm})$ peats from forest $(\mathrm{F})$, drained (D), recently planted (RP) and mature oil palm (MOP) sites. Carbon dioxide fluxes are shown from time point one and methane from time point four. The pattern in the data was the same at the different time points. Means \pm one SEM. $n=5$. 
Cooper, H., Vane, C.H., Evers, S., Aplin, P., Girkin, N., Sjogersten, S. 2019. From peat swamp forest to oil palm plantations: the stability of tropical peatland carbon. Geoderma 342, 109-117 https://doi.org/10.1016/j.geoderma.2019.02.021

Table 4. Gas flux statistics from different land uses and depths assessed by REML. Significant differences in italics.

\begin{tabular}{llllllllll}
\hline & $\mathbf{C H}$ & & & & $\mathbf{C O}$ & & & \\
& F-statistic & d.f. & $\mathbf{p}$ & SED & F-statistic & d.f. & p & SED \\
\hline Land use & 5.57 & 3,16 & $<0.05$ & 0.02 & 9.4 & 3,16 & $<0.001$ & 0.02 \\
Depth & 37.57 & 1,48 & $<0.001$ & 0.01 & 63.7 & 1,48 & $<0.001$ & 0.01 \\
Temp & 12.75 & 1,48 & $<0.001$ & 0.02 & 35.1 & 1,48 & $<0.001$ & 0.01 \\
Land use*Depth & 9.8 & 3,48 & $<0.001$ & 0.02 & 8.28 & 3,48 & $<0.001$ & 0.02 \\
Land use*Temp & 0.33 & 3,48 & 0.806 & 0.02 & 0.18 & 3,48 & 0.909 & 0.02 \\
Depth*Temp & 6.53 & 1,48 & $<0.05$ & 0.01 & 3.05 & 1,48 & 0.087 & 0.01 \\
Land use*Depth*Temp & 1.37 & 3,48 & 0.264 & 0.03 & 0.59 & 3,48 & 0.623 & 0.03 \\
\hline
\end{tabular}

\subsection{Relationships between Organic Matter Properties and $\mathrm{CO}_{2}$ and $\mathrm{CH}_{4}$ Fluxes}

The scores and loading of the first and second principal components accounted for most of the variance for surface and subsurface peats, $60 \%$ and $50 \%$ respectively. The surface peats (Fig. $6 a \&$ c) display clustering in each land use, demonstrating a difference in Rock-Eval parameters between sites, whereas in subsurface peats (Fig. $6 \mathrm{~b} \& \mathrm{~d}$ ) there appears to be no clustering of parameters for each land use. In surface samples, mature oil palm sites are best described by TpkS2 and OI, whereas drained sites are predominantly separated by S1, S2 and $\mathrm{C}_{1}$ parameters (Fig. 6c). $\mathrm{CO}_{2}$ fluxes are regulated by TpkS2 in surface peat but by $\mathrm{S} 2$ and $\mathrm{HI}$ in subsurface peats and in contrast, $\mathrm{CH}_{4}$ fluxes are regulated by $\mathrm{C}_{\mathrm{i}}$ pool in subsurface peats (Fig. 6d). 
Cooper, H., Vane, C.H., Evers, S., Aplin, P., Girkin, N., Sjogersten, S. 2019. From peat swamp forest to oil palm plantations: the stability of tropical peatland carbon. Geoderma 342, 109-117 https://doi.org/10.1016/j.geoderma.2019.02.021

a) $\Delta$ Forest $\quad$ Recently Planted

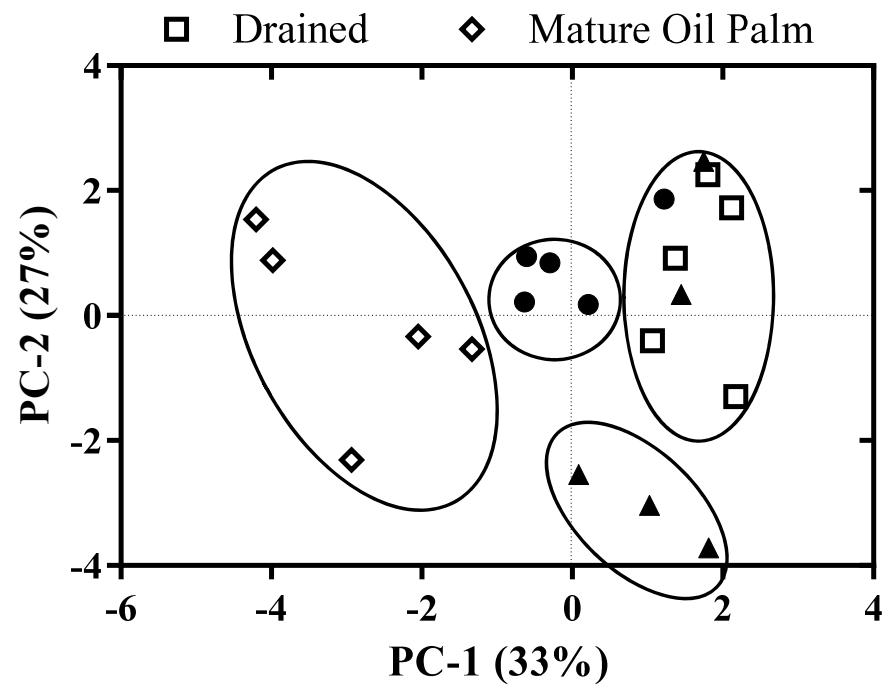

c)

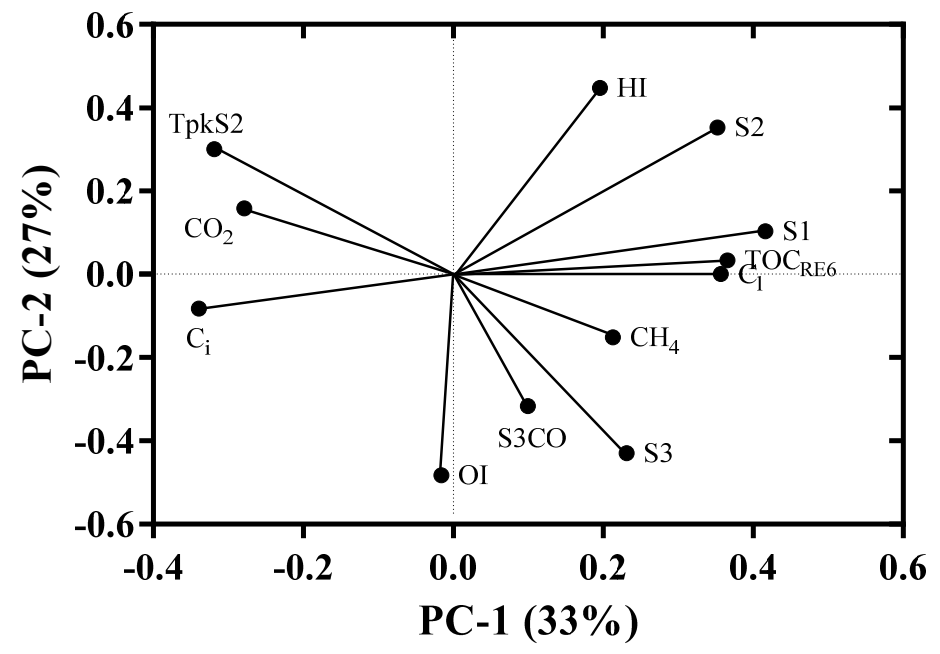

b)

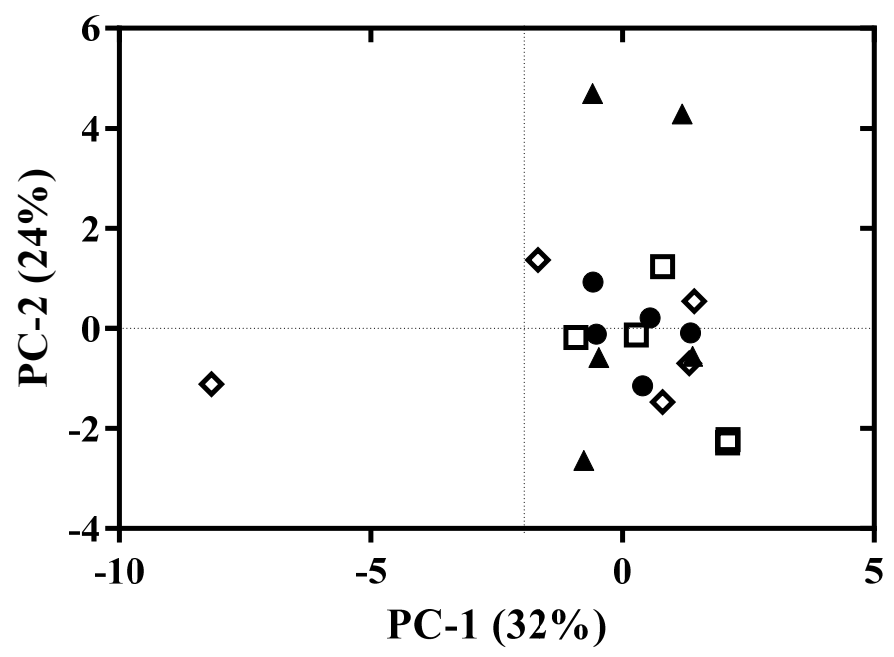

d)

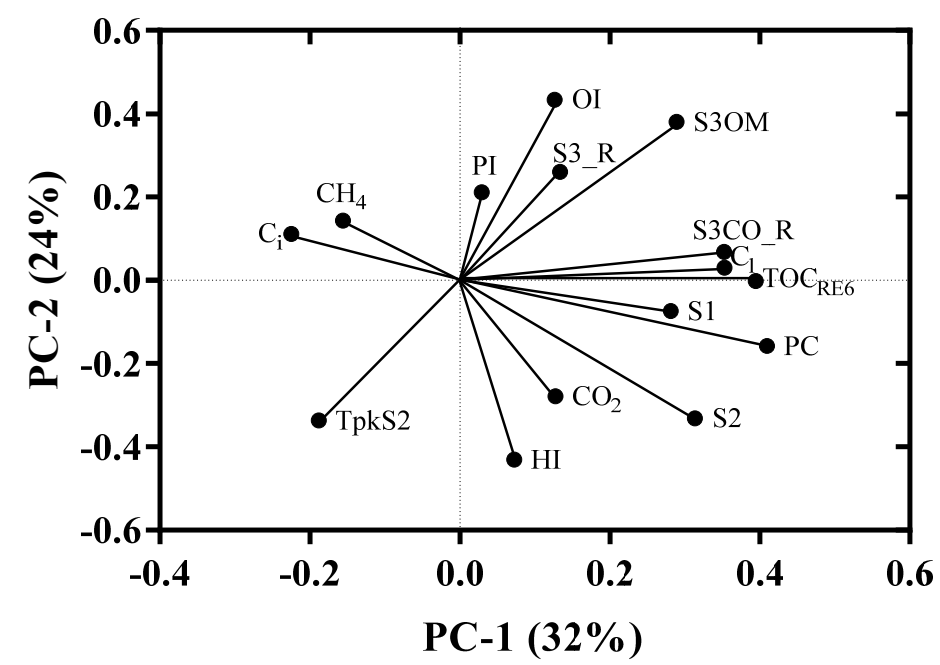

Figure 6. Principal component scores (a\&b) and loadings (c\&d) for Rock-Eval parameters and carbon dioxide and methane fluxes from surface $(a \& c)$ and subsurface $(b \& d)$ peats. Combined PC1 and PC2 account for $60 \%$ and $56 \%$ of the variance respectively. 
Cooper, H., Vane, C.H., Evers, S., Aplin, P., Girkin, N., Sjogersten, S. 2019. From peat swamp forest to oil palm plantations: the stability of tropical peatland carbon. Geoderma 342, 109-117 https://doi.org/10.1016/j.geoderma.2019.02.021

\section{Discussion}

\subsection{Depletion of labile substrates with conversion to oil palm plantation}

The clear decrease in the size of the labile carbon with land conversion (from ca 70 to less than $20 \%$ when comparing forest and mature oil palm), together with an increasing intermediate carbon pool (from ca 20 to $70 \%$ when comparing forest and mature oil palm) in surface peat but not in deeper peats (Fig. 4), supported the first hypothesis, which predicted that losses of labile carbon with land conversion would be most pronounced in surface peat. Depletion of labile carbon pools and a relative build-up of more recalcitrant carbon in surface peat is in line with selective depletion of carbohydrates and decreasing carbohydrate to aromatics ratios and peat loss following land conversion demonstrated at these and other sites in Southeast Asia (Tonks et al., 2017; Matysek et al., 2017; Kononen et al., 2017). This is further supported by the greater thermostability of the surface peat at the mature oil palm sites than forested and drained forested sites (Fig. 6a and c), which previously have been linked to peat degradation in tropical peatlands in Panama (Upton et al., 2018).

The changes in peat organic chemistry are linked to two main processes. First, lowered watertables increase the oxygenation of the peat surface layer and enhances the degradation of organic polymers by bacteria and fungi (Couwenberg et al., 2010; Konenen et al 2016). The different responses between the surface and deeper peats to land use change in this study clearly demonstrates the impact of the long term position of the water-table in peat, with the loss of labile carbon above the water-table, and the preservation of significant quantities labile organic material below the water-table.

Second, the shift in the vegetation litter inputs following conversion will also strongly impact on the relative abundance of the different carbon pools. In PSF, the vegetation adds carbon to 
Cooper, H., Vane, C.H., Evers, S., Aplin, P., Girkin, N., Sjogersten, S. 2019. From peat swamp forest to oil palm plantations: the stability of tropical peatland carbon. Geoderma 342, 109-117 https://doi.org/10.1016/j.geoderma.2019.02.021

the peat surface as litter and into the peat from the rhizosphere, and thus contributes to maintenance of the peat carbon stores by compensating for carbon losses that result from concurrent decomposition (Jauhiainen et al., 2016). PSF litter is composed largely of coarse and fine roots, woody debris and leaf litter, and is rich in both cellulosic and more complex ligneous substrates (Miyajima et al., 1997; Hoyos-Santillan et al., 2015). However, as lignin is resistant to decomposition and ligninolytic microbes are obligate aerobes (Zeikus, 1981), the amount of cellulosic substrates decreases as peat decomposition advances even under anoxic condition, explaining the depletion of labile carbon with depth even at the forest sites (HoyosSantillan et al., 2015).

\subsection{Linking $\mathrm{CO}_{2}$ and $\mathrm{CH}_{4}$ fluxes and organic matter properties}

As expected, potential $\mathrm{CO}_{2}$ production from flooded peat was several orders of magnitude higher than $\mathrm{CH}_{4}$ production as shown previously in both disturbed and natural tropical wetlands (IPCC 2014; Hoyos-Santillan et al., 2016), with fluxes of similar magnitude but slightly lower than those from pristine Neotropical peatlands (Sjogersten et al., 2018). Furthermore, emissions were consistently higher in surface peats suggesting these have greater production potential than degraded subsurface peats, likely reflecting substrate limitation of microbial decomposition processes with depth (Wright et al., 2011; Hoyos-Santillan et al., 2016; Sihi et al., 2018; Upton et al., 2018) but other factors may also play a role, e.g. shifts in the microbial community structure with depth in response to changes in peat properties (Jackson et al., 2009). The successive reduction in ex situ $\mathrm{CO}_{2}$ and $\mathrm{CH}_{4}$ fluxes from waterlogged peat with progressively more advanced land conversion stage, together with the parallel depletion of labile carbon in surface peat (Fig. 5) suggests that the labile carbon pools strongly control GHG 
Cooper, H., Vane, C.H., Evers, S., Aplin, P., Girkin, N., Sjogersten, S. 2019. From peat swamp forest to oil palm plantations: the stability of tropical peatland carbon. Geoderma 342, 109-117 https://doi.org/10.1016/j.geoderma.2019.02.021

emissions in line with the second hypothesis. Similar strong links between GHG fluxes (from water logged peat) and peat organic chemistry has previously been shown for undisturbed peatlands (Wright et al., 2011; Hoyos-Santillan et al., 2016), with greater fluxes found from peat with larger labile carbon pools. In contrast, no changes in GHG production was found with land conversion from the deeper peats which is likely due to limited impacts of land conversion on decomposition deeper in the peat profile which remained below the water-table also after drainage.

These findings clearly demonstrate that the loss of peat due to enhanced decomposition following conversion result in more recalcitrant peat which limits GHG emissions under waterlogged conditions. However, it is important to note that this substrate limitation of GHG emissions is most likely controlled by the anaerobic conditions which limits the microbial communities' capacity to utilise more complex organic molecules. Under aerobic conditions, $\mathrm{CO}_{2}$ fluxes would likely remain high across the conversion gradient as has been shown in situ in peatlands in South Selangor, Malaysia (Matysek et al., 2017), as the oxygen availability support the activity of microbial communities capable of degradation of complex organic molecules (Hoyos-Santillan et al., 2016).

The relatively lower fluxes of both $\mathrm{CO}_{2}$ and especially $\mathrm{CH}_{4}$ from the mature oil palm sites suggest that although re-flooding of oil palm plantations may result in some $\mathrm{CH}_{4}$ emissions in line with Jauhiainen et al., (2016), raising water-tables will not increase $\mathrm{CH}_{4}$ emissions to the levels of those found in intact PSFs in the short term. Limited increases in $\mathrm{CH}_{4}$ production following rewetting of peats that have been exposed to prolonged periods of oxic conditions has been reported previously from high latitude peatlands (Sjogersten et al., 2016) as well as tropical peatlands (Jauhianen et al., 2008). This is likely linked to slow recovery of the methanogenic communities from oxic peat conditions. Indeed, functional shifts in microbial 
Cooper, H., Vane, C.H., Evers, S., Aplin, P., Girkin, N., Sjogersten, S. 2019. From peat swamp forest to oil palm plantations: the stability of tropical peatland carbon. Geoderma 342, 109-117 https://doi.org/10.1016/j.geoderma.2019.02.021

community composition e.g. decline in macro fungi abundance, in response to conversion of PSF to oil palm plantations at has been shown previously at these sites (Rajihan et al., 2017; Shuhada et al., 2017) suggesting that strong impacts of land conversion should be expected on the microbially mediated decomposition processes. In the longer term, microbial communities and pools of labile substrates may recover if water-tables are raised and the native vegetation reintroduced (Jauhianen et al., 2008; 2016). As PSFs have higher percentage of canopy cover and denser canopy closure (Yule and Gomez, 2009) and greater litter inputs than oil palm plantation (Guillaume et al., 2015), restoring PSF would likely increase pools of labile organic matter in surface peats which could shift microbial community functionality towards its original form, restoration of microbial community functionality has been shown to be limited 3.5 years after forest restoration (Nurulita et al., 2016).

\subsection{Impact of temperature on surface and subsurface fluxes}

The strong impact of temperature on both anaerobic $\mathrm{CO}_{2}$ and $\mathrm{CH}_{4}$ fluxes suggests that their production is highly sensitive to higher temperatures in line with findings from tropical peatlands in Panama (Sjögersten, et al 2018). The anaerobic $\mathrm{CO}_{2}$ fluxes were consistently higher at 30 than $25{ }^{\circ} \mathrm{C}$ across depths and land conversion stages suggesting that the microbial community was temperature limited. The substantial increase in anaerobic $\mathrm{CO}_{2}$ fluxes at the forest and drained sites at the $30{ }^{\circ} \mathrm{C}$ treatment indicate that the large labile $\mathrm{C}$ pool at these sites (Fig. 4.) supports high $\mathrm{CO}_{2}$ emissions (Wright et al., 2011; Hoyos Santillan et al., 2016, Duval and Radu 2018) and that forested peatland sites may represent a substantial positive ecosystem feedback. 
Cooper, H., Vane, C.H., Evers, S., Aplin, P., Girkin, N., Sjogersten, S. 2019. From peat swamp forest to oil palm plantations: the stability of tropical peatland carbon. Geoderma 342, 109-117 https://doi.org/10.1016/j.geoderma.2019.02.021

$\mathrm{CH}_{4}$ production was more temperature sensitive at sites with degraded peat (oil palm sites) supporting kinetic theory that postulates greater energy demands for degradation of complex organic molecules (Bosatta and Agren 1999; Davidson and Janssens 2006). Indeed, $\mathrm{CH}_{4}$ emissions at $30^{\circ} \mathrm{C}$ were comparable among land use classes, suggesting that high temperatures $\left(30{ }^{\circ} \mathrm{C}\right.$ in this study) overcome substrate limitation of $\mathrm{CH}_{4}$ production. This compares with anaerobic incubations studies of mineral subtropical wetland soils that also report comparable $\mathrm{CH}_{4}$ emissions among land uses (ranging from agricultural to riparian forest) at $30{ }^{\circ} \mathrm{C}$ despite differences among land uses for anaerobic $\mathrm{CO}_{2}$ fluxes (Moore et al., 2018).

\subsection{Conclusion}

Surface peat carbon was consistently higher in surface than deeper peats and was greatest in forest sites, with relative decreases following land conversion. GHG fluxes were also greatest from surface peats and declined alongside labile carbon. Higher temperatures also drove higher GHG fluxes but the magnitude of the temperature response was dependent on organic matter lability. While the increase in $\mathrm{CO}_{2}$ fluxes was greatest at forest sites, higher temperatures increases $\mathrm{CH}_{4}$ emissions at both forest and converted sites, implying that increasing temperature due to climate warming may drive higher $\mathrm{CH}_{4}$ fluxes from sites dominated by degraded organic matter. This study demonstrates that the enhanced decomposition and reduced litter input rates is reflected in reduced potential $\mathrm{CO}_{2}$ emissions but that higher temperature resulting from climate warming may maintain high GHG emissions at plantation sites.

\section{References}


Cooper, H., Vane, C.H., Evers, S., Aplin, P., Girkin, N., Sjogersten, S. 2019. From peat swamp forest to oil palm plantations: the stability of tropical peatland carbon. Geoderma 342, 109-117 https://doi.org/10.1016/j.geoderma.2019.02.021

Bosatta, E., Ågren, G.I., 1999. Soil organic matter quality interpreted thermodynamically. Soil Biol. Biochem. 31, 1889-1891. doi:10.1016/S0038-0717(99)00105-4

Climate Change 2014 Synthesis Report for Policymakers, 2014. IPCC. IPCC 31. doi:10.1017/CBO9781107415324

Comeau, L.-P., Hergoualc'h, K., Smith, J., Verchot, L., 2013. Conversion of intact peat swap forest to oil palm plantation: Effects on CO2 fluxes in Jambi, Sumatra. Cent. Int. For. Res. 8.

Corley, R.H. V, 2009. How much palm oil do we need? Environ. Sci. Policy 12, 134-139. doi:10.1016/j.envsci.2008.10.011

Dargie, G.C., Lewis, S.L., Lawson, I.T., Mitchard, E.T.A., Page, S.E., Bocko, Y.E., Ifo, S.A., 2017. Age, extent and carbon storage of the central Congo Basin peatland complex. Nature 542, 86-90. doi:10.1038/nature21048

Davidson, E.A., Janssens, I.A., 2006. Temperature sensitivity of soil carbon decomposition and feedbacks to climate change. Nature 440, 165-173. doi:10.1038/nature04514

Disnar, J.R., 1994. Determination of maximum paleotemperatures of burial (MPTB) of sedimentary rocks from pyrolysis data on the associated organic matter: basic principles and practical application. Chem. Geol. 118, 289-299. doi:10.1016/0009-2541(94)90182-1

Disnar, J.R., Guillet, B., Keravis, D., Di-Giovanni, C., Sebag, D., 2003. Soil organic matter (SOM) characterization by Rock-Eval pyrolysis: Scope and limitations. Org. Geochem. 34, 327-343. doi:10.1016/S0146-6380(02)00239-5

Espitalié, J., Deroo, G., Marquis, F., 1985. La pyrolyse Rock-Eval et ses applications: Première partie. Rev. l'Institut Fr. du Pet. 40, 563-579. doi:10.2516/ogst:1985035 
Cooper, H., Vane, C.H., Evers, S., Aplin, P., Girkin, N., Sjogersten, S. 2019. From peat swamp forest to oil palm plantations: the stability of tropical peatland carbon. Geoderma 342, 109-117 https://doi.org/10.1016/j.geoderma.2019.02.021

Evers, S., Yule, C.M., Padfield, R., O’Reilly, P., Varkkey, H., 2017. Keep wetlands wet: the myth of sustainable development of tropical peatlands - implications for policies and management. Glob. Chang. Biol. 23, 534-549. doi:10.1111/gcb.13422

Girkin, N. T., Turner, B. L., Ostle, N., Craigon, J. \& Sjogersten, S. 2018. Root exudate analogues accelerate $\mathrm{CO} 2$ and $\mathrm{CH} 4$ production in tropical peat. Soil Biology \& Biochemistry, $117,48-55$

Guillaume, T., Damris, M., Kuzyakov, Y. 2015. Losses of soil carbon by converting tropical forest to plantations: erosion and decomposition estimated by d13C. Global Change Biology, $21,3548-3560$

Global Environment Centre, 2014. Integrated management plan for North Selangor peat swamp forest 2014-2023 for Selangor state forestry department.

IPCC, 2007. Working Group I Report “The Physical Science Basis.” PCC Fourth Assess. Rep. IPCC, 2006. Wetlands. 2006 IPCC Guidel. Natl. Greenh. Gas Invent. Prep. by Natl. Greenh. Gas Invent. Program. 1-24. doi:citeulike-article-id:1930815

IPCC, 2000. Land Use, Land-Use Change, and Forestry. Forestry 1-9. doi:DOI: $10.2277 / 0521800838$

Jauhiainen, J., Page, S.E., Vasander, H., 2016. Greenhouse gas dynamics in degraded and restored tropical peatlands. Mires \& Peat 17, 1-12. doi:10.19189/MaP.2016.OMB.229

Johannes, I., Kruusement, K., Veski, R., Bojesen-Koefoed, J.A., 2006. Characterisation of pyrolysis kinetics by Rock-eval basic data. Oil Shale 23, 249-257.

Koh, L.P., Wilcove, D.S., 2008. Is oil palm agriculture really destroying tropical biodiversity? Conserv. Lett. 1, 60-64. doi:10.1111/j.1755-263X.2008.00011.x 
Cooper, H., Vane, C.H., Evers, S., Aplin, P., Girkin, N., Sjogersten, S. 2019. From peat swamp forest to oil palm plantations: the stability of tropical peatland carbon. Geoderma 342, 109-117 https://doi.org/10.1016/j.geoderma.2019.02.021

Kumari, K., 1996. An application of the incremental cost framework to biodiversity conservation: a wetland case study in Malaysia. Work. Pap. - Cent. Soc. Econ. Res. Glob. Environ. GEC 96-15.

Miettinen, J., Hooijer, A., Vernimmen, R., Liew, S.C., Page, S.E., 2017. From carbon sink to carbon source: Extensive peat oxidation in insular Southeast Asia since 1990. Environ. Res. Lett. 12. doi:10.1088/1748-9326/aa5b6f

Miettinen, J., Shi, C., Liew, S.C., 2016. Land cover distribution in the peatlands of Peninsular Malaysia, Sumatra and Borneo in 2015 with changes since 1990. Glob. Ecol. Conserv. 6, 6778. doi:10.1016/j.gecco.2016.02.004

Miyajima, T., Wada, E., Hanba, Y.T., Vijarnsorn, P., 1997. Anaerobic mineralization of indigenous organic matters and methanogenesis in tropical wetland soils. Geochim. Cosmochim. Acta 61, 3739-3751. doi:10.1016/S0016-7037(97)00189-0

Moore, B.D., Kaur, G., Motavalli, P.P., Zurweller, B.A., Svoma, B.M., 2018. Soil greenhouse gas emissions from agroforestry and other land uses under different moisture regimes in lower Missouri River Floodplain soils: a laboratory approach. Agrofor. Syst. 92, 335-348. doi:10.1007/s10457-017-0083-8

Nurulita, Y., Adetutu, E. M., Gunawan, H., Zul, D., Ball, A. S. 2016. Restoration of tropical peat soils: The application of soil microbiology for monitoring the success of the restoration process. Agriculture Ecosystems \& Environment, 216, 293-303.

Page, S.E., Morrison, R., Malins, C., Hooijer, A., Rieley, J.O. Jaujiainen, J., 2011. Review of Peat Surface Greenhouse Gas Emissions from Oil Palm Plantations in Southeast Asia. Indirect Eff. Biofuel Prod. 1-77. 
Cooper, H., Vane, C.H., Evers, S., Aplin, P., Girkin, N., Sjogersten, S. 2019. From peat swamp forest to oil palm plantations: the stability of tropical peatland carbon. Geoderma 342, 109-117 https://doi.org/10.1016/j.geoderma.2019.02.021

Saenger, A., Cécillon, L., Sebag, D., Brun, J.J., 2013. Soil organic carbon quantity, chemistry and thermal stability in a mountainous landscape: A Rock-Eval pyrolysis survey. Org. Geochem. 54, 101-114. doi:10.1016/j.orggeochem.2012.10.008

Sebag, D., Disnar, J.R., Guillet, B., Di Giovanni, C., Verrecchia, E.P., Durand, A., 2006. Monitoring organic matter dynamics in soil profiles by "Rock-Eval pyrolysis": Bulk characterization and quantification of degradation. Eur. J. Soil Sci. 57, 344-355. doi:10.1111/j.1365-2389.2005.00745.x

Sjögersten, S., Aplin, P., Gauci, V., Peacock, M. Siegenthaler, A., Turner, B., 2018. Temperature response of ex-situ greenhouse gas emissions from tropical peatlands: interactions between forest type and peat moisture conditions. Unpublished.

Tonks, A.J., Aplin, P., Beriro, D.J., Cooper, H., Evers, S., Vane, C.H., Sjögersten, S., 2017. Impacts of conversion of tropical peat swamp forest to oil palm plantation on peat organic chemistry, physical properties and carbon stocks. Geoderma 289, 36-45. doi:10.1016/j.geoderma.2016.11.018

Upton, A., Vane, C.H., Girkin, N. T., Turner, B.L., Sjögersten, S., 2018. Does litter input determine carbon storage and peat organic chemistry in tropical peatlands? Geoderma 326, 7687.

Vijay, V., Pimm, S.L., Jenkins, C.N., Smith, S.J., 2016. The Impacts of Oil Palm on Recent Deforestation and Biodiversity Loss. PLoS One 1-19. doi:10.1371/journal.pone.0159668

Yule, C.M., Gomez, L.N., 2009. Leaf litter decomposition in a tropical peat swamp forest in Peninsular Malaysia. Wetl. Ecol. Manag. 17, 231-241. doi:10.1007/s11273-008-9103-9 
Cooper, H., Vane, C.H., Evers, S., Aplin, P., Girkin, N., Sjogersten, S. 2019. From peat swamp forest to oil palm plantations: the stability of tropical peatland carbon. Geoderma 342, 109-117 https://doi.org/10.1016/j.geoderma.2019.02.021

Yule, C.M., Lim, Y.Y., Lim, T.Y., 2018. Recycling of phenolic compounds in Borneo's tropical peat swamp forests. Carbon Balance Manag. 13. doi:10.1186/s13021-018-0092-6

Zeikus, J. G. 1981. Lignin Metabolism and the Carbon-Cycle - Polymer Biosynthesis, Biodegradation, and Environmental Recalcitrance. Advances in Microbial Ecology, 5, 211243. 